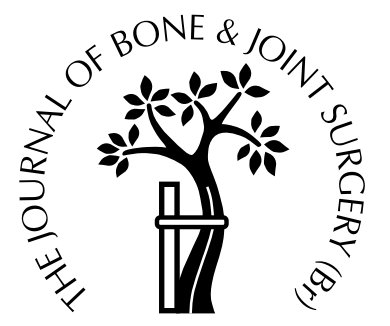

\title{
Insulin-like growth factor-I enhances cell-based repair of articular cartilage
}

\author{
L. A. Fortier, H. O. Mohammed, G. Lust, A. J. Nixon \\ From Cornell University College of Veterinary Medicine, Ithaca, USA
}

C romposites of chondrocytes and polymerised fibrin were supplemented with insulin-like growth factor-I (IGF-I) during the arthroscopic repair of full-thickness cartilage defects in a model of extensive loss of cartilage in horses. Repairs facilitated with IGF-I and chondrocyte-fibrin composites, or control defects treated with chondrocyte-fibrin composites alone, were compared before death by the clinical appearance and repeated analysis of synovial fluid, and at termination eight months after surgery by tissue morphology, collagen typing, and biochemical assays. The structure of cartilage was evaluated histologically by Toluidine Blue reaction and collagen type-I and type-II in situ hybridisation and immunohistochemistry. Repair tissue was biochemically evaluated by DNA assay, proteoglycan quantitation and characterisation, assessment of collagen by reverse-phase high-performance liquid chromatography, and collagen typing using cyanogen bromide digestion and peptide separation by polyacrylamide gel electrophoresis.

The results at eight months showed that the addition of IGF-I to chondrocyte grafts enhanced chondrogenesis in cartilage defects, including incorporation into surrounding cartilage. Gross filling of defects was improved, and the tissue contained a higher proportion of cells producing type-II collagen. Measurements of collagen type II showed improved levels in IGF-I-treated defects, supporting in situ hybridisation and immunohistochemical assessments of the defects. IGF-I improves the repair capabilities of

L. A. Fortier, DVM, PhD, Assistant Professor, Molecular Medicine H. O. Mohammed, DVM, PhD, Professor, Population Medicine and Diagnostic Sciences

G. Lust, PhD, Professor, James A. Baker Institute for Animal Health A. J. Nixon, BVSc, MS, Professor and Director, Comparative Orthopaedics Laboratory

James A. Baker Institute for Animal Health, College of Veterinary Medicine, Cornell University, Ithaca, New York 14853, USA.

Correspondence should be sent to Mr A. J. Nixon.

(C)2002 British Editorial Society of Bone and Joint Surgery 0301-620X/02/211167\$2.00 chondrocyte-fibrin grafts in large full-thickness repair models.

J Bone Joint Surg [Br] 2002;84-B:276-88.

Received 15 March 2000; Accepted after revision 25 August 2000

Injuries to articular cartilage are common in adults and may lead to the development of osteoarthritis because of the poor repair response of cartilage. ${ }^{1-4}$ Despite extensive research, a universally acceptable method for resurfacing of articular cartilage has not been reported. Many procedures for the transplantation of cartilage have been used in animal studies and human clinical trials with varying results. The advances in cartilage repair achieved by the use of osteochondral allografts and autografts, and periosteal and perichondrial transplantations alone or in conjunction with mesenchymal or chondrocyte transplantation, have been comprehensively reviewed. $^{5-7}$ More recently, the use of biological or synthetic tissue-engineered matrices for resurfacing of cartilage has received considerable attention. ${ }^{8-15}$ The application of in vitro amplified, cryopreserved chondrocytes in the constructs reduces or eliminates the need for a donor site, and malleable constructs can be applied arthroscopically, further improving patient acceptance. Biological matrices such as hyaluronan, collagen type-I and type-II sponges, alginate, agarose and fibrin have been used in vitro to study the metabolism of chondrocytes resulting in an extensive pool of knowledge regarding their function in these matrices. Additionally, the effects of growth factors on their metabolism have been investigated in many of these biological matrices. ${ }^{15-21}$ It is likely that some of these products may also be used in vivo as carriers for various growth factors to enhance the repair response of the transplanted cells and the host chondrocytes surrounding the defect.

Several growth factors are known to enhance the synthesis of cartilage matrix. ${ }^{22-27}$ In particular, insulin-like growth factor-I (IGF-I) has specific anabolic effects. ${ }^{28-33}$ The addition of IGF-I to explants of cartilage or to monolayer cultures of chondrocytes increased the synthesis of large aggregating proteoglycans and type-II collagen, while inhibiting the degradation and release of proteoglycans. In explant cultures, the addition of IGF-I to culture medium has also been shown to maintain the mechanical and electromechanical properties of the explant cartilage. ${ }^{34}$ 
Depending on the culture medium, cell density, and conditions used in the experiment (explant, artificial threedimensional matrix, or monolayer), IGF-I may also stimulate DNA and the synthesis of type-II collagen. ${ }^{28,35-38}$ The effects of IGF-I on chondrocyte metabolism and matrix synthesis have also been investigated in a three-dimensional fibrin culture system in which IGF-I maintained chondrocyte morphology and enhanced the phenotypic expression of large proteoglycans and type-II collagen, without stimulating the synthesis of type-I collagen or inducing dedifferentiation of chondrocytes to a fibroblastlike cell shape. ${ }^{39,40}$ In addition to the anabolic effects of IGF-I on normal articular cartilage, there is evidence that IGF-I is beneficial to injured cartilage. The degradation of matrix after exposure of cartilage to interleukin-1 and/or tumour necrosis factor $\alpha$ can be partially alleviated or protected by treatment with IGF-I. ${ }^{32,41,42}$

Based on these experiments in vitro, IGF-I was further evaluated before cartilage healing studies in vivo. Laboratory studies showed that IGF-I could be incorporated into fibrin during polymerisation from fibrinogen, and would subsequently elute at concentrations sufficient to enhance chondrocyte phenotypic expression (50 to $100 \mathrm{ng} / \mathrm{ml}$ ) for 14 to 22 days. ${ }^{39,43}$ Fibrin has previously been reported to be an effective vehicle for the transfer of chondrocytes ${ }^{44}$ and for the application of growth factors. ${ }^{15}$ Fibrin-chondrocyte composites are injectable, arthroscopically applicable, cartilage graft materials. ${ }^{44}$ Experimental studies using large articular defects showed that the technique resulted in improved cartilage repair tissue, characterised biochemically and histologically as hyaline-like, but not normal articular cartilage. Our aim in this experiment was to show that the addition of IGF-I to fibrin-chondrocyte composites grafted to large, full-thickness, articular cartilage defects further enhanced the quality of the resultant repair tissue.

\section{Materials and Methods}

This project was approved and performed according to the guidelines of the Institutional Animal Care and Use Committee.

Chondrocyte isolation and graft preparation. Articular cartilage was taken from the patellofemoral joints of four horses, aged from four to eight months. Chondrocytes were isolated from the matrix by digestion in $0.075 \% \mathrm{w} / \mathrm{v}$ collagenase in medium, and cryopreserved as previously described. ${ }^{45}$ The medium consisted of Harms's F-12 medium containing $50 \mu \mathrm{g} / \mathrm{ml}$ of ascorbic acid, $30 \mu \mathrm{g} / \mathrm{ml}$ of $\alpha$-ketoglutaric acid, $300 \mu \mathrm{g} / \mathrm{ml}$ of L-glutamine, $10 \%$ fetal calf serum, $100 \mathrm{units} / \mathrm{ml}$ of sodium penicillin, and $100 \mu \mathrm{g} /$ $\mathrm{ml}$ of streptomycin sulphate (all from Gibco Life Technologies, Gaithersburg, Maryland). For each animal, isolated chondrocytes were thawed and cultured in monolayer for two days at $5.3 \times 10^{5}$ cells $/ \mathrm{cm}^{2}$. They were then trypsinised, separated into two aliquots of $20 \times 10^{6}$ viable chondrocytes, centrifuged, and the cell pellets were resus- pended in $1 \mathrm{ml}$ of a sterile equine fibrinogen solution prepared as described below. We then added $25 \mu \mathrm{g}$ of IGF-I (human recombinant, splice variant IGF-1A; Genentech Inc, San Francisco, California) to one of the two suspensions of fibrinogen and cells.

Fibrinogen was prepared by sodium acetate-ethanol precipitation $^{46}$ of pooled plasma from the same four horses used for the donation of chondrocytes. The fibrinogen was lyophilised, sterilised by gamma irradiation, and resuspended to $200 \mathrm{mg} / \mathrm{ml}$ in medium. This method of isolation of fibrinogen is temperature- $\left(0^{\circ} \mathrm{C}\right)$ and $\mathrm{pH}(7.2)$-controlled to provide reproducible precipitation of non-denatured fibrinogen. In addition, $2 \mathrm{ml}$ of calcium-activated sterile equine thrombin (Sigma Chemical Co, St Louis, Missouri) were also prepared for polymerisation of fibrinogen during graft implantation.

Operative procedure. We used eight adult horses ranging in age from three to five years and free from abnormalities of the femoropatellar joint. Antibiotics and a non-steroidal antiinflammatory agent were given before and after operation. The horses were anaesthetised, placed in dorsal recumbency, and the femoropatellar joints were prepared aseptically for arthroscopic surgery. Samples of synovial fluid were withdrawn, an arthroscope was inserted sequentially into both of the femoropatellar joints and the articulations were explored to rule out any pre-existing cartilage lesions. A guarded spade bit cutter $15 \mathrm{~mm}$ in diameter, premeasured to drill $3 \mathrm{~mm}$ deep, was introduced into the joints through a second portal and used to create a single cartilage defect in the mid-lateral trochlear ridge of each femur. This method removes all the superficial layers of articular cartilage and most of the calcified cartilage layer, but is not deep enough to excise all of the calcified cartilage in horses two to five years of age. Any remaining calcified cartilage, readily observable in the horse, was removed with a surgical curette to the level of subchondral bone. Two $1.2 \mathrm{~mm}$ polylactic acid copolymer tacks (Biofix minitack; Biosience Ltd, Finland) were inserted into the defect to serve as anchors for the fibrin graft. The fluid medium used for distension was replaced by sterile helium gas, and the subchondral bed of the cartilage lesion dried by inserting several lint-free sponges. The left or right leg was chosen at random to receive an IGF-I supplemented fibrin/ chondrocyte graft. The contralateral articular defect in the same horse received a fibrin/chondrocyte graft without IGF-I and served as the control. For each leg, the fibrinogen-cell slurry ( $\pm 25 \mu \mathrm{g}$ of IGF-I) and thrombin were mixed on injection into the cartilage defect. The joints were irrigated with fluid to remove residual gas and the skin incisions were closed. After surgery, the horses were confined to a stall for six weeks and then allowed walking exercise for ten minutes daily, which increased each week.

Samples of synovial fluid were withdrawn from both femoropatellar joints on days 4, 7, 14, 21 and 28 after surgery and when the animals were killed at eight months. The samples were analysed for cell morphology, total and differential white blood cell count, protein concentration by Coo- 
Table I. Scoring system used for the gross appearance

\begin{tabular}{lll}
\hline Analysis & Score & Qualifications \\
\hline Surface texture & 0 & Normal: smooth, hyaline \\
of repair tissue & 1 & $>75 \%$ normal \\
& 2 & $50 \%$ to $75 \%$ normal \\
Percent area of & 3 & $<50 \%$ normal \\
defect filled & 0 & $100 \%$ \\
& 1 & $>75 \%$ \\
Graft-recipient tissue & 2 & $50 \%$ to $75 \%$ \\
integration & 3 & $<50 \%$ \\
& 1 & $100 \%$ of perimeter \\
& 2 & $>75 \%$ \\
& 3 & $<50 \%$ \\
\hline
\end{tabular}

Table II. Scoring system used for histological examination of the synovial membrane

\begin{tabular}{lll}
\hline Analysis & Score & Qualifications \\
\hline Villus thickening & 0 & Normal \\
(fibrosis) & 1 & Slightly increased \\
& 2 & Moderately increased \\
& 3 & Severely increased \\
Villus architecture & 0 & Normal shape \\
(blunting) & 1 & Slight clubbing \\
& 2 & Moderate clubbing \\
& 3 & Severe clubbing \\
Inflammatory cell & 0 & Normal (none) \\
infiltrate & 1 & Slightly increased \\
& 2 & Moderately increased \\
& 3 & Severely increased \\
\hline
\end{tabular}

Table III. Scoring system used for repair tissue

\begin{tabular}{lll}
\hline Analysis & Score & Qualifications \\
\hline Depth of defect filled (\%) & 1 & 111 to 125 \\
& 0 & 91 to 110 \\
& 1 & 76 to 90 \\
& 2 & 51 to 75 \\
Integration with adjacent cartilage & 0 & 26 to 50 \\
& 4 & $<25$ \\
Surface architecture & 1 & Normal continuity \\
& 2 & Gap on one side \\
& 0 & Normal, smooth \\
Cellular morphology and & 1 & Slight fibrillation or irregularity \\
organisation (\%) & 2 & Moderate fibrillation \\
& 3 & Severe fibrillation \\
Cellularity relative to adjacent & 0 & 100 normal \\
cartilage (\%) & 1 & $>75$ normal \\
& 2 & 25 to 75 normal \\
Tidemark formation (\%) & 3 & $<25$ normal \\
& 1 & Decreased $>10$ \\
to adjacent cartilage (\%) & 0 & Decreased $<10$ \\
& 1 & Normal \\
& 2 & Increased $<10$ \\
& 0 & Increased $>10$ \\
& 1 & 75 to 90 complete \\
& 2 & 50 to 74 complete \\
& 3 & 25 to 49 complete \\
& 4 & $<25$ \\
& 0 & Normal \\
& 1 & Decreased $<25$ \\
& & Decreased $>25$ \\
\hline
\end{tabular}

massie Blue spectrophotometric assay, and the hyaluronan content by Alcian Blue spectrophotometric assay.

Retrieval of tissue. After the horses had been killed, the joints were opened and photographed. The gross appearance of the repair tissue was evaluated with the investigators unaware of the treatment group. A composite healing score was based on three variables (Table I). A rectangular block comprising the central one-third of the repair tissue plus 3 to $5 \mathrm{~mm}$ of surrounding intact cartilage and underlying subchondral bone were removed with a bone saw and fixed in $4 \%$ paraformaldehyde for histological examination. The remaining repair tissue was removed from the site of the lesion. Cartilage was also removed from an area $1 \mathrm{~cm}$ away from the lesion (perilesional) and more than $2 \mathrm{~cm}$ away from this area (remote) for biochemical analysis. Samples of cartilage from each location were weighed, frozen and pulverised in a freezer mill to obtain homogenous samples. One-third of each sample was papaindigested for analysis of DNA and total glycosaminoglycan, and the remaining two-thirds were used for proteoglycan aggregation ability by agarose-acrylamide composite gel electrophoresis, collagen typing by cyanogen bromide digestion and polyacrylamide gel electrophoresis as well as determination of total collagen by reverse-phase high-performance liquid chromatography (rpHPLC).

Histological examination. Cartilage and the underlying subchondral bone were decalcified in $10 \%$ EDTA, embedded in paraffin, and sectioned at $6 \mu \mathrm{m}$. The sections were stained with haematoxylin and eosin to evaluate the mor- phology and with Toluidine Blue to assess the distribution of proteoglycans in the pericellular matrix. The synovial membrane and sections of decalcified cartilage-bone were evaluated by two investigators (LAF, AJN) each of whom was unaware of the treatment group (IGF-I or control). The synovial membrane was evaluated for three parameters, and the decalcified cartilage-bone sections for seven parameters (Tables II and III). For each tissue type, total scores from the two investigators were averaged for statistical evaluation.

In situ hybridisation. Sections were prepared for hybridisation to procollagen type I and type II using a modification of techniques described previously. ${ }^{47}$ The generation and application of equine-specific type-II procollagen riboprobes have been described. ${ }^{40}$ In brief, riboprobes were synthesised from a 201bp cDNA encoding exons 1 to 7 of equine type-IIB procollagen mRNA, corresponding to positions 138 to 339 of the available equine coding sequence (Genbank accession number U62528). Riboprobes for procollagen type I were generated from a 254bp cDNA encoding exons 1 to 2 of the $\mathrm{NH}_{2}$-propeptide region, corresponding to positions 1 to 254 of the equine coding sequence (Genbank accession number AF034691). Antisense and sense $\left({ }^{35} \mathrm{~S}\right)$-UTP (Dupont-NEN)-labelled riboprobes were transcribed on EcoRI-linearised pGEM-3zF(+) DNA templates (Promega Corporation, Madison, Wisconsin).

The tissue sections were covered with probe and incubat- 
ed overnight at $43^{\circ} \mathrm{C}$ in a moist chamber. After incubation, the coverslips were washed off in $2 \times$ sodium citrate/ sodium chloride (SSC), the slides were washed in $2 \mathrm{SSC} /$ $0.5 \%$ beta-mercaptoethanol at $50^{\circ} \mathrm{C}$ for 15 minutes, and in $0.5 \times \mathrm{SSC} / 0.5 \%$ beta-mercaptoethanol at $50^{\circ} \mathrm{C}$ for one hour. The slides were then treated with RNaseA $(20 \mu \mathrm{g} / \mathrm{ml})$ in $0.5 \mathrm{M} \mathrm{NaC} 1,10 \mathrm{mM}$ Tris, $\mathrm{pH} 7.5$, and $5 \mathrm{mM}$ EDTA at $37^{\circ} \mathrm{C}$, and lastly washed in $2 \times \mathrm{SSC} / 50 \%$ formamide $/ 0.5 \%$ beta-mercaptoethanol at $45^{\circ} \mathrm{C}$ for two hours. The sections were dehydrated through a graded series of alcohols containing $300 \mathrm{mM}$ ammonium acetate, dried, and dipped in NTB2 emulsion (Eastman Kodak Co, Rochester, New York), and exposed for 14 days. The emulsion was developed, sections were counterstained with haematoxylin, and examined under light and darkfield microscopy. All sections were processed in the same batch. For type-II procollagen, cartilage from the femoral trochlear ridge of a juvenile horse served as a positive control tissue, and negative control tissues consisted of skin and superficial flexor tendon. The latter served as a positive control tissue section for type-I procollagen and cartilage from the femoral trochlear ridge was the negative control tissue. Senseprobe was applied to sections from each experimental group and control tissues as a control for non-specific background hybridisation.

Immunocytochemistry. Sections were treated with $5 \mu \mathrm{g} / \mathrm{ml}$ of testicular hyaluronidase at $37^{\circ} \mathrm{C}$ for 60 minutes, and endogenous peroxidases were exhausted with hydrogen peroxide and methanol. Normal goat serum was applied for 30 minutes to block non-specific binding, and the sections were then incubated with polyclonal rat anti-bovine type-II collagen primary antibody (1:100) (courtesy of Dr Michael Cremer, Veterans Administration Hospital, Memphis, Tennessee) or rabbit anti-equine type-I collagen primary antibody. Secondary antibody (supersensitive multilink; BioGenex, San Ramone, California) was applied, followed by streptavidin-conjugated peroxidase label (BioGenex) to catalyse chromogen development in 3-amino-9-ethylcarbazol (AEC; Vector Laboratories Inc, Burlingame, California). Sections were counterstained with Harris haematoxylin, and examined by microscopy to determine the distribution of type-I and type-II collagen. Positive control samples for type-II collagen were derived from equine chondrocytes cultured in monolayer for three days, and negative controls consisted of tendon and skin sections. For type-I collagen, positive control samples consisted of equine tendon, and negative controls were chondrocytes cultured in monolayer for three days. Negative control reactions for each antibody were performed by substituting the primary antibody with non-immune serum applied to serial sections of each experimental tissue.

DNA analysis. Total DNA was determined on duplicate $100 \mu \mathrm{l}$ aliquots of papain digests incubated for 24 hours at $65^{\circ} \mathrm{C}$. The samples were mixed with bisbenzimide (Sigma) compound for DNA quantification by fluorometric assay. ${ }^{48}$ Calf thymus DNA was used to prepare a standard curve.

\section{Proteoglycan analysis}

Total glycosaminoglycans. The total content of glycosaminoglycan in the papain-digested samples of cartilage was assayed by the dimethyl-methylene blue dye binding (DMMB) spectrophotometric assay. ${ }^{49}$ Mixed-isomer shark chondroitin sulphate was used to construct the standard curve.

Proteoglycan aggregation. Proteoglycans were extracted from $10 \mu \mathrm{g}$ of frozen, pulverised tissues at $4{ }^{\circ} \mathrm{C}$ with $4 \mathrm{M}$ GuHCL in $0.05 \mathrm{M}$ sodium acetate buffer containing protease inhibitors $(\epsilon$-amino- $n$-caproic acid $(0.1 \mathrm{M})$, benzamidine $\mathrm{HCl}(10 \mathrm{mM})$, pepstatin $\mathrm{A}(1 \mu \mathrm{M})$ phenylmethylsulphonyl fluoride $(10 \mathrm{mM}), \mathrm{Na}_{2}$ EDTA $(10 \mathrm{mM})$ (all from Sigma). Extracted proteoglycans were dialysed overnight in water and allowed to aggregate in the presence of exogenous hyaluronan $(10 \% \mathrm{w} / \mathrm{w})$ at $4^{\circ} \mathrm{C}$. The resulting proteoglycans in water were lyophilised, resuspended in $60 \%$ sucrose loading buffer, and electrophoresed in large-pore composite agarose-polyacrylamide gels. ${ }^{50,51}$ Proteoglycan bands were visualised by staining with Toluidine Blue dye $(0.2 \%(\mathrm{w} / \mathrm{v})$ in $100 \mathrm{mM}(\mathrm{v} / \mathrm{v})$ acetic acid) for 20 minutes followed by destaining in $3 \%(\mathrm{v} / \mathrm{v})$ acetic acid. The large pore construction of the agarose-polyacrylamide gels makes it possible to distinguish proteoglycan aggregates, which cannot enter the gel matrix, from dissociated glycosaminoglycans which can migrate within the gel matrix.

\section{Collagen analyses}

Total collagen quantification. As an estimate of total collagen, the content of hydroxyproline in the repair tissue and surrounding cartilage was assessed by rpHPLC. ${ }^{52}$ In duplicate, $800 \mu \mathrm{g}$ of lyophilised sample were added to tared hydrolysis vials and hydrolysed in $6 \mathrm{~N} \mathrm{HC} 1$ at $110^{\circ} \mathrm{C}$ for 22 hours on a hydrolysis work station (Waters Division, Millipore Corp, Millford, Massachusetts). The hydrolysed samples were derivatised with phenylisothiocyanate and $1 \mu \mathrm{g}$ was analysed by rpHPLC on a $15 \mathrm{~cm} \mathrm{C-18}$ column (PICOTag, Waters Division, Millipore), eluted using a gradient of $6 \%$ to $31 \%$ acetonitrile in $140 \mathrm{mM}$ sodium acetate with $0.05 \%$ triethylamine at $\mathrm{pH} 5.7$. The column was maintained at $46^{\circ} \mathrm{C}$, with a flow rate of $1 \mathrm{ml} / \mathrm{min}$ for the separation phase. Commercial software packages (Maxima Software, Waters Division, Millipore) utilised for controlling and integration procedures, provided total hydroxyproline values from a standard curve of mixed amino acids.

Collagen typing. The content of collagen type II was assessed in 3 to $4 \mathrm{mg}$ of each lyophilised sample by cleavage in cyanogen bromide and separation of marker peptides characteristic of type-I and type-II collagen on a $12 \%$ polyacrylamide-sodium dodecylsulphate gel (SDSPAGE). Varying proportions of purified equine collagen type-I and type-II marker peptides were also run on SDSPAGE to construct a standard curve. The polyacrylamide gels were scanned on a laser scanning densitometer $(590 \mathrm{~nm})$ to determine the relative intensity of the collagen type-I and type-II peptides. The area under the bands representing peaks of $\alpha 1(\mathrm{II}) \mathrm{CB} 10$ and $\alpha 2(\mathrm{I}) \mathrm{CB} 3,5$ were 
used to form a ratio of the amount of type-II to type-I collagen, respectively, which was converted to a percent type II from the standard curve. ${ }^{14}$

Synovial fluid analyses. Total and differential cell counts and synovial fluid smear analyses were performed by routine Coulter counting, and assessment of Giemsa-stained smears. Total protein in synovial fluid was determined by the method of Bradford, ${ }^{53}$ using Coomassie Brilliant Blue G-250 Dye (Bio-Rad, Richmond, California). The concentration of hyaluronan in samples of synovial fluid was determined by an Alcian Blue subtractive spectrophotometric assay. 54

IGF-I radioimmunoassay. Elution of IGF-1 from fibrinchondrocyte grafts into the synovial fluid was determined by competitive binding radioimmunoassay (RIA) according to the manufacturer's directions (Nichols Institute Diagnostics, San Juan Capistrano, California). Briefly, $100 \mu \mathrm{l}$ of synovial fluid were incubated with $900 \mu$ l of acid-ethanol solution $(12.5 \% 2 \mathrm{~N} \mathrm{HCl} / 87.5 \% \mathrm{v} / \mathrm{v})$ to dissociate IGF-I from IGF-binding proteins. The resulting solution was incubated at room temperature for 30 minutes, followed by centrifugation to precipitate IGF-binding proteins. The supernatant was neutralised by adding $0.86 \mathrm{M}$ Tris-Base and a second centrifugation was performed to avoid interference by further precipitate. Rabbit anti-IGF-I serum was added to the supernatant and allowed to incubate for one hour, followed by competition with ${ }^{125}$ I IGF-I for 16 hours. Precipitating complex (normal rabbit serum preprecipitated with goat anti-rabbit serum and polyethylene glycol) was added to each sample. The samples were centrifuged, and the amount of precipitated IGF-I was determined by gamma scintillation counting and comparison with a standard curve prepared from samples supplied by the manufacturer.

Statistical analysis. With each animal serving as its own control, a two-tailed paired $t$-test was used to determine significant differences between IGF-I-treated and control repair tissue for gross appearance scores, histological scores from decalcified cartilage-bone sections and synovial tissue samples, mean $\mu \mathrm{g}$ DNA/mg dry weight, mean $\mu \mathrm{g}$ GAG/mg dry weight, mean pg hydroxyproline/ $\mu \mathrm{g}$ dry weight, and percent type-II collagen. To determine differences in mean $\mu \mathrm{g}$ DNA/mg dry weight, mean $\mu \mathrm{g}$ GAG/ mg dry weight, mean pg hydroxyproline/ $\mu \mathrm{g}$ dry weight, and percent type-II collagen between repair tissue (lesional), perilesional ( $1 \mathrm{~cm}$ from lesion), and remote $(>2 \mathrm{~cm}$ from lesion) sites within the IGF-I-treated or control grafted joint, a one-way analysis of variance (ANOVA) was performed. Tukey's post-hoc test was utilised for ANOVAs with significant F-tests. Statistical analyses for differences in cell count, total protein and hyaluronan content in synovial fluid between IGF-I-treated and control joints were performed by analysis of covariance with time as a covariate to account for expected postoperative changes. A p value of " 0.05 was considered to be significant.

\section{Results}

Morphology. Gross examination of the IGF-I-treated lesions showed that they were filled more completely with repair tissue, and integration into the surrounding cartilage was improved compared with control joints (Fig. 1). The overall gross assessment score was significantly improved (lower) for IGF-I-treated lesions compared with the control defects $(\mathrm{p}=0.030)$ with the largest influence arising from improved integration of the graft composite into the surrounding cartilage. There was no evidence of infiltration of inflammatory cells, lysis, or formation of cysts in the subchondral bone of IGF-I-treated or control joints. Histological examination of sections of synovial membrane revealed that IGF-I-treated joints had a significantly improved (lower) score than control joints, predominantly influenced by increased villus blunting in control compared with IGF-I-treated joints $(\mathrm{p}=0.050)$. In control joints, there was moderate hyperplasia and blunting of villi and occasional foci of lymphoid hyperplasia in the synovium, indicative of chronic inflammation.

Subgross photomicrographs indicated that the addition of IGF-I to fibrin-chondrocyte composites improved the overall continuity and consistency of repair tissue formed in the $15 \mathrm{~mm}$ full-thickness defects, supporting the gross observations (Figs 2A and 2B). In IGF-I-supplemented grafts, the repair tissue had less surface fibrillation, improved integration with surrounding cartilage and increased filling of the articular defect. The mean cartilage histological score in the IGF-I-treated joints was not significantly different from that of control joints, but Toluidine Blue matrix metachromasia was significantly improved in IGF-I-treated lesions ( $\mathrm{p}=0.030$ ) (Figs $2 \mathrm{C}$ and 2D). In the Toluidine Blue histological sections and all other types of histological examina-

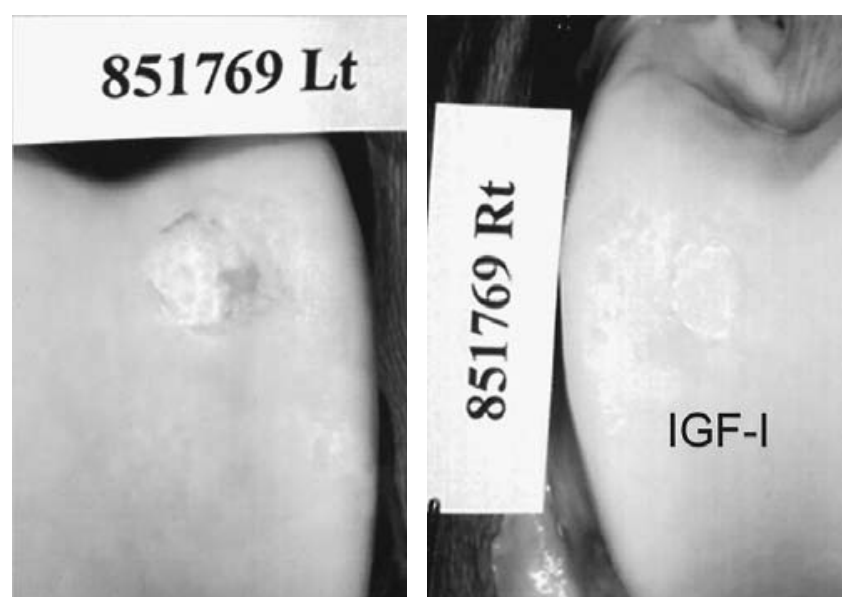

Fig. 1

Photographs of the gross appearance of control (left) and IGF-I (right) grafted defects at eight months. The depth and surface area of repair tissue in the IGF-I-treated defect are greater and more consistent with normal surrounding articular cartilage than in the control defect, and the repair tissue in the IGF-I-treated defects is more congruous with the surrounding articular surface than in the control repair tissue. 
A

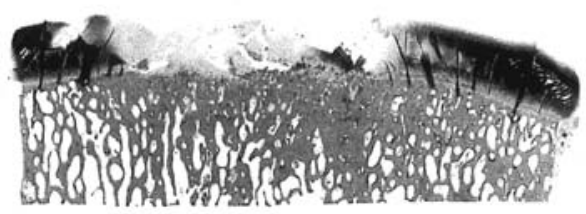

C

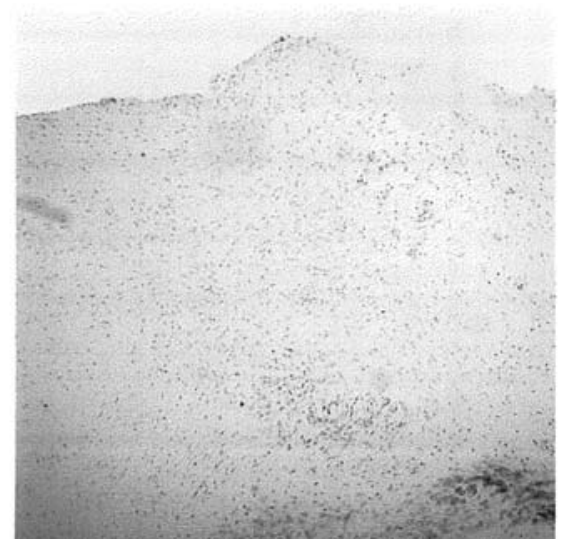

B

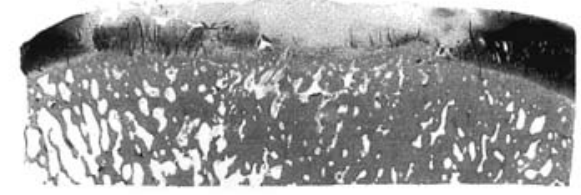

D

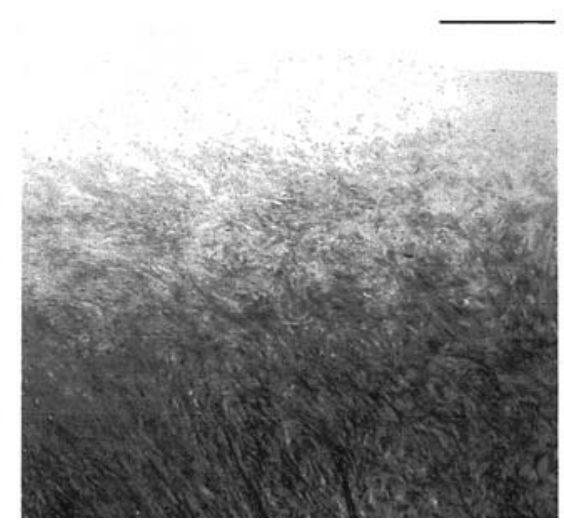

Fig. 2

Photomicrographs showing the subgross histological appearance of the entire $15 \mathrm{~mm}$ cartilage defect and underlying subchondral bone eight months after grafting with chondrocytes/fibrin (control) (A) or chondrocytes/ fibrin/IGF-I (B) and Toluidine Blue staining of control (C) or IGF-I supplemented (D) repair tissue. There is a significantly increased intensity and distribution of matrix metachromasia in the IGF-I supplemented repair tissue (A, B, haematoxylin and eosin, bar $=5 \mathrm{~mm} ; \mathrm{C}, \mathrm{D}$ bar $=80 \mu \mathrm{m})$.

tion performed, expression and synthesis of the various molecules examined were greatest in the deepest layers of the healing tissue and decreased in intensity toward the surface. Although not statistically significant, the cellularity and pattern of cell distribution in repair tissue facilitated by IGF-I supplementation appeared to be more organised and less like fibrous tissue than in control defects (Figs 3A and 3B). The difference in cellular organisation between IGF-Itreated and control defects was also apparent at the junction between repair and surrounding cartilage (Figs 3C and 3D). The integration of cell and matrix patterns between repair and surrounding cartilage in the IGF-I-treated joints was significantly improved $(\mathrm{p}=0.050)$ compared with control joints, supporting the gross observations.

Immunohistochemical and in situ hybridisation localisation of collagen types I and II was also evaluated by two investigators (LAF, AJN) who were unaware of the treatment grouping. Quantitative assessments were not evaluated statistically because of interanimal variation, but general trends emerged when comparing intra-animal IGF-I-treated with control repair tissue. Type-II collagen gene expression and type-II collagen immunolocalisation were greater in IGF-I-treated lesions of six horses and no differences were seen in two horses, compared with control joints (Fig. 4). There was a low level of type-I procollagen mRNA expression in the repair tissue of six horses, with an obvious difference in expression detected in four in which the IGF-I-treated defects were expressing less type-I procollagen than the control defects (Fig. 5 ). There was no detectable difference in the type-I procollagen in situ reaction in the repair tissue of the remaining two horses. Immunoreaction to collagen type I was present in the repair tissue of seven horses. In four positive for type-I collagen, synthesis was greater in the control defect compared with IGF-I-treated defects; no differences in type-I collagen immunoreaction could be detected in the remaining three horses.

DNA content. There was significantly greater DNA content in the repair tissue in both joints compared with perilesion and remote cartilage (Fig. 6). There was no significant difference in the DNA content between IGF-Itreated and control joints in lesion, perilesion and remote cartilage.

\section{Proteoglycan analysis}

Total glycosaminoglycan content. There was significantly less glycosaminoglycan in the repair tissue of both the IGFI-treated and control limbs than in perilesional or remote cartilage, which were not different from each other (Fig. 7). There was no significant difference in the glycosaminoglycan content between IGF-I-treated and control limbs.

Proteoglycan aggregation ability. Proteoglycans extracted from IGF-I-treated and control grafted defects were capable of forming large aggregates (Fig. 8). Agarose-acrylamide 

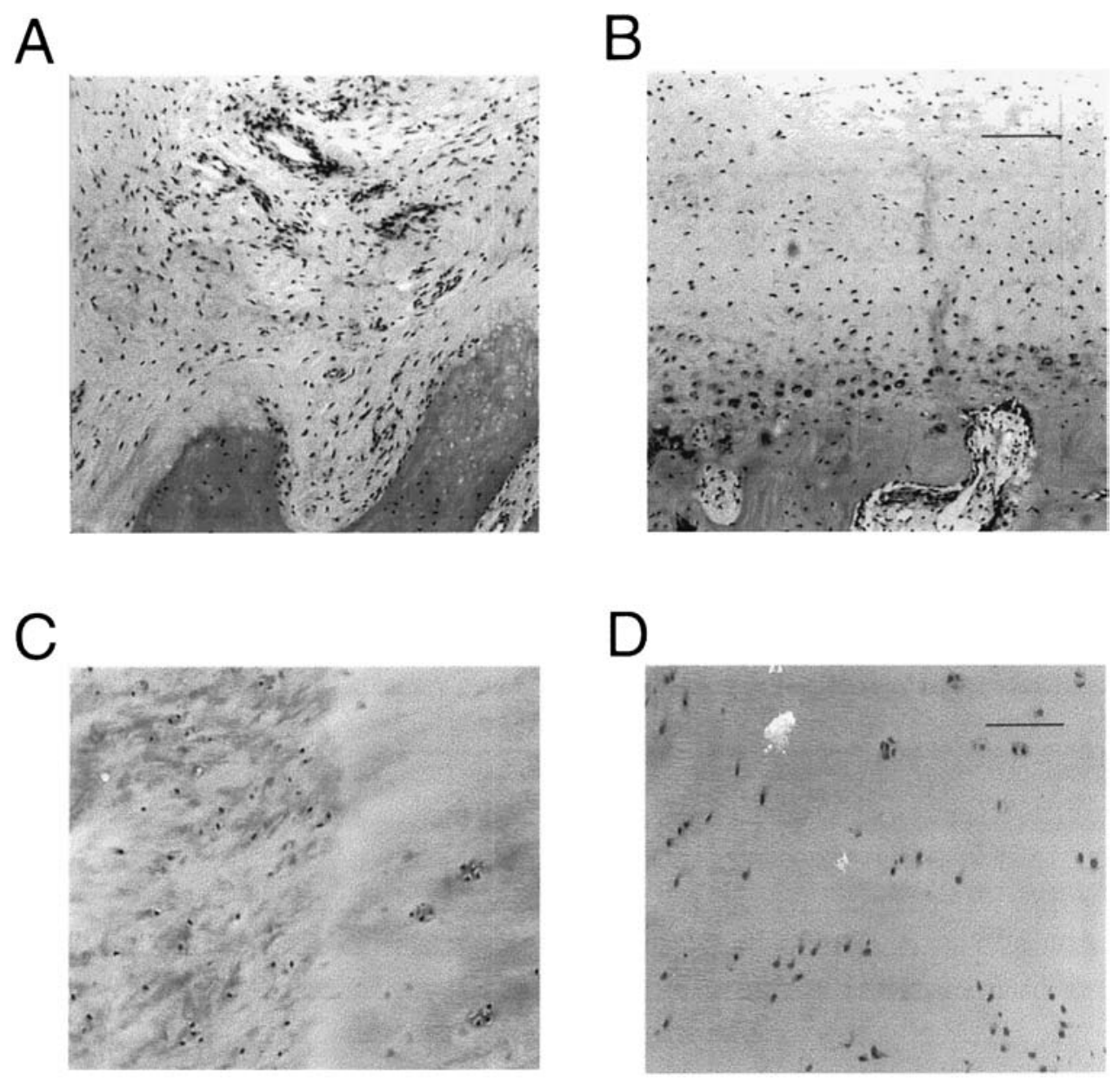

Fig. 3

Photomicrographs showing the histological appearance of the cellular distribution of the repair tissuesubchondral bone interface. Figures 3A and 3B - IGF-I supplemented repair tissue (B) appears to be more organised and less fibrous than control repair tissue (A) (haematoxylin and eosin, $b a r=60 \mu \mathrm{m}$ ). Figures $3 \mathrm{C}$ and 3D - Region between repair tissue and surrounding articular cartilage in control grafted (C) and IGF-Isupplemented (D) defects. There is better integration between repair tissue and surrounding cartilage in IGF-Itreated repair tissue than in the control (haematoxylin and eosin, bar $=50 \mu \mathrm{m}$ ).

composite gels stained with Toluidine Blue showed the ability of proteoglycans extracted from lesion, perilesion and remote cartilage from two different experimental horses, to form large aggregates. The large aggregates were incapable of entering the composite gel and remained at the very top of the gel because of their large size. Proteoglycans extracted from IGF-I and control grafted defect sites were all capable of forming large aggregates.

Collagen analysis. Total hydroxyproline content, as an estimate of the total collagen content, was not significantly different in repair tissue, perilesion or remote cartilage in IGF-I-treated or control joints and there were no differences between IGF-I-treated and control joints (Table IV). The percentage of type-II collagen, however, determined by CNBr-cleavage and SDS-PAGE analysis, in repair tissue of IGF-I-treated defects was significantly greater than that of type-II collagen in control defects (Fig. 9). There were no significant differences between perilesion or remote cartilage, and the percentage of type-II collagen in repair tissue from both limbs was significantly less than perilesion or remote cartilage.

Synovial fluid analysis. Synovial fluid nucleated cell counts and total protein were increased after surgery, while the content of hyaluronan was decreased on day 4 and day 7 , returning to preoperative values by day 21 . There were no significant differences in nucleated cell count $(\mathrm{p}=0.11)$, total protein $(p=0.77)$, or hyaluronan content $(p=0.81)$ between IGF-I-treated and control joints at any time period (days $0,4,7,14,21,28$ and 8 months). The amount of IGFI in synovial fluid from IGF-I-treated joints increased at day 4, but no significant differences in the quantity of IGF-I were detected by RIA in the synovial fluid between IGF-Itreated and control joints at any time (Table V).

\section{Discussion}

This long-term study indicates that the addition of IGF-I to chondrocyte-fibrin biomatrix grafts enhances the quality of 

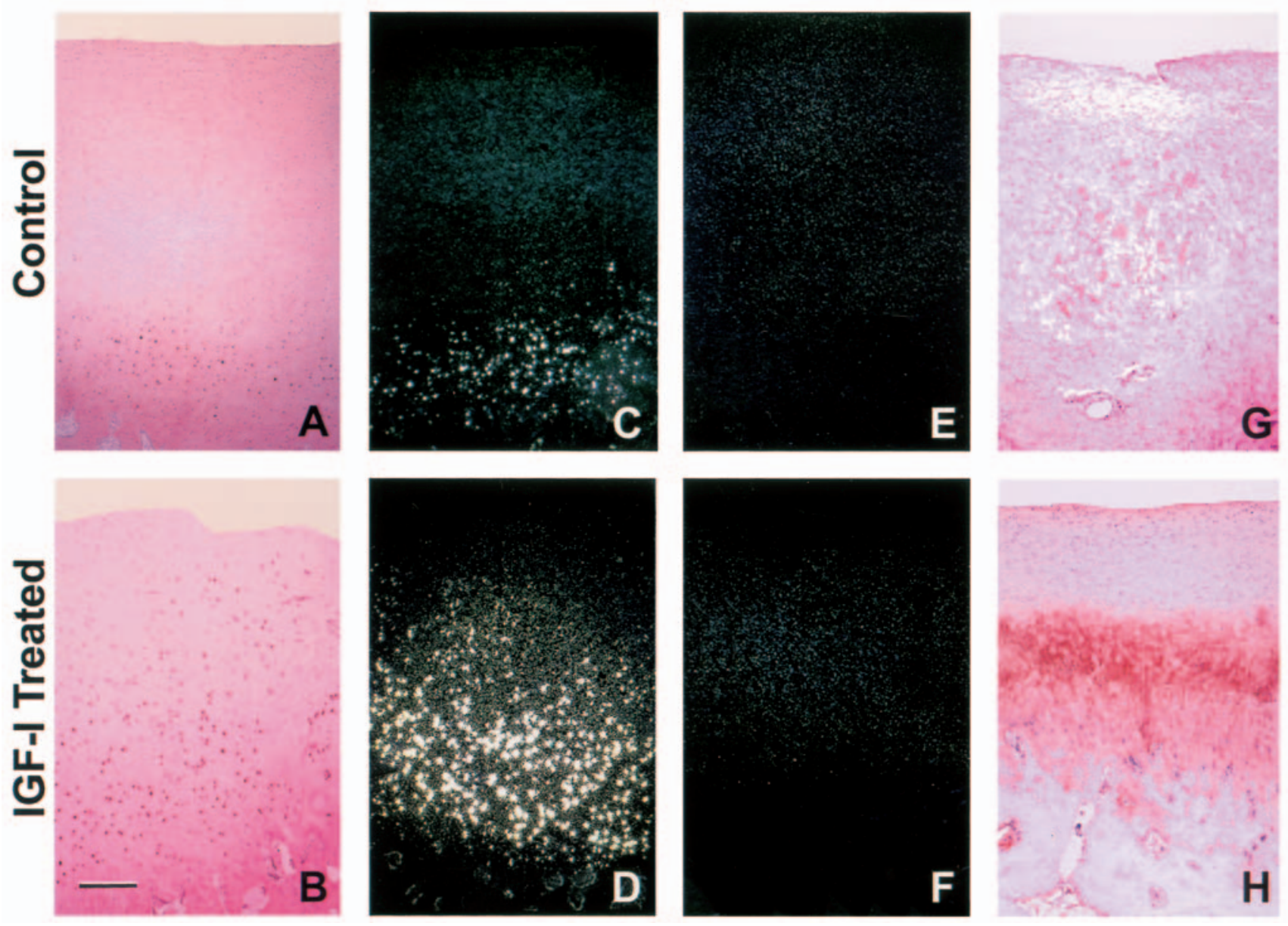

Fig. 4

Photomicrographs of type-II procollagen in situ hybridisation and immunohistochemistry in repair tissue from control (top row) and IGF-I-grafted (bottom row) defects. Figures 4A to 4D - Differential expression of total type-II procollagen mRNA determined by in situ hybridisation; A and B are brightfield photomicrographs, and $\mathrm{C}$ and $\mathrm{D}$ are the same sections photographed under darkfield illumination. Figures $4 \mathrm{E}$ and $4 \mathrm{~F}-\mathrm{Similar}$ tissue sections hybridised with sense-orientated probes and photographed with darkfield illumination to serve as a control group. Figures $4 \mathrm{G}$ and $4 \mathrm{H}-\mathrm{Type-II}$ collagen immunocytochemistry of repair tissues. There is more abundant and intense in situ hybridisation and immunoreaction in the deeper layers of IGF-I supplemented grafts than in control-grafted defects.

the repair tissue formed in large, full-thickness, cartilage defects. IGF-I was selected in preference to other growth factors based on previous studies which showed that IGF-I added to articular cartilage can stimulate co-ordinated synthesis of aggrecan, hyaluronan, link protein, and type-II collagen, inhibit degradation of proteoglycans, and maintain a net tissue balance of proteoglycans and the equilibrium modulus and electrokinetic coefficient of the tissue. $^{28,31,33,34,55-57}$ Further, IGF-I has been shown to protect partially and aid recovery of cartilage after matrix degradation by IL- 1 and/or TNF- $\alpha$, suggesting a beneficial role for IGF-I in the healing of injured cartilage. ${ }^{32,41}$

Fibrin and chondrocytes without added IGF-I were chosen as the control graft material to isolate and test the added effects of IGF-I supplementation on cartilage repair in vivo. Previous studies performed using the same dimensioned defects in equine femoropatellar defects showed that the repair tissue formed was significantly improved in defects grafted with fibrin containing chondrocytes compared with spontaneous repair in empty defects. ${ }^{44}$ An additional contributing factor to our choice of control in this study was the observation that improvements in articular repair were noted when the fibrin or collagen graft matrices also contained chondrocytes compared with fibrin or collagen matrices devoid of chondrocytes. ${ }^{14,58}$ Although repeat arthroscopies or serial necropsies were not performed to ensure the continued presence of graft composites in the defects, there are several previous studies using the same model system as described in this report which provide information regarding the capacity for spontaneous repair in empty defects. ${ }^{44,59}$ These studies revealed that there is negligible spontaneous repair tissue formed in empty defects, and combined with results of the current experiment, confirm the improved quantity and quality of repair tissue in defects grafted with combinations of fibrin/chondrocyte/IGF-I.

The postoperative synovial fluid parameters in this study were within the normal range for those following arthro- 

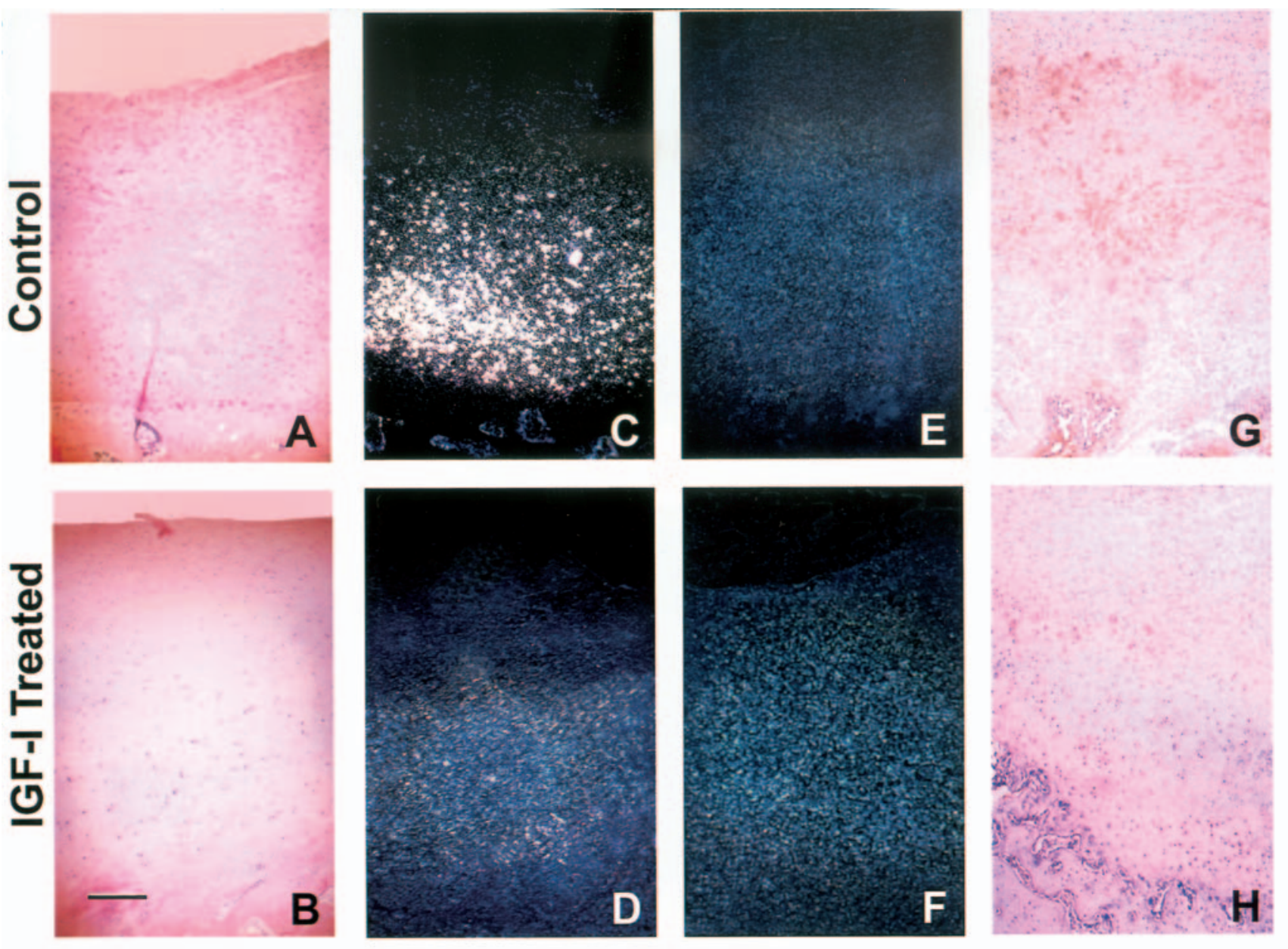

Fig. 5

Photomicrographs of type-I procollagen in situ hybridisation and immunohistochemistry in repair tissue from control (top row) and IGF-I-grafted (bottom row) defects. Figures 5A to 5D - Differential expression of total type-I procollagen mRNA determined by in situ hybridisation. A and B are brightfield photomicrographs and $\mathrm{C}$ and $\mathrm{D}$ are the same sections photographed under darkfield illumination. Figures $5 \mathrm{E}$ and $5 \mathrm{~F}-\mathrm{Similar}$ tissue sections hybridised with sense-orientated probes and photographed with darkfield illumination to serve as control group. Figures $5 \mathrm{G}$ and $5 \mathrm{H}-\mathrm{Type}-\mathrm{I}$ collagen immunocytochemistry of repair tissues. There is more abundant and intense in situ hybridisation and immunoreaction in the deeper layers of control grafted defects than in IGF-I supplemented grafts.

scopy in clinical patients. There was no severe synovial inflammation, or increased articular heat, pain or swelling which would indicate an adverse reaction to the graft composites in either the control or IGF-I-treated joints. Indeed, the eight-month histological score for the synovial membrane in the IGF-I-treated joints was significantly improved compared with that in control joints. This may reflect an IGF-I-induced protection of the synovial membrane from the postoperative inflammatory response recorded during the initial 28 days. White blood cell counts in synovial fluid from IGF-I-treated joints taken at days 4 and 7 were reduced, suggesting that there was some dampening of the degree of synovitis in these joints. Additionally, improved cover of the subchondral bone by new cartilage in IGF-supplemented defects may have decreased the general synovial reaction between the day-28 assay and harvest of tissues after eight months, thereby reducing the pathological scores for the synovial membrane.

Morphological markers of chondrogenesis, including metachromatic pericellular staining on Toluidine Blue histochemistry and collagen type-II predominance on in situ hybridisation and immunohistochemical studies, all supported a beneficial, matrix-enhancing effect of IGF-I. There was variation in the degree of response mounted by individual animals in the quality of repair tissue formed, but general patterns were evident. The most transcriptionally and translationally active cells were located in the deep layers of the defects. Cells in the middle zone were less active, and cells in the superficial layers were quiescent. It is unclear why there was such an obvious gradient in cellular responses but similar patterns are characteristic of most healing large defects in cartilage. Possible explanations include enhanced graft nutrition from the vascular supply of subchondral bone, a more prolific pool of cells in the deeper layers derived from mesenchymal cells of subchondral bone, and the negative influence of mechanical activity on the healing surface layers of the articular tissues. Type-II collagen message and protein were present in all 


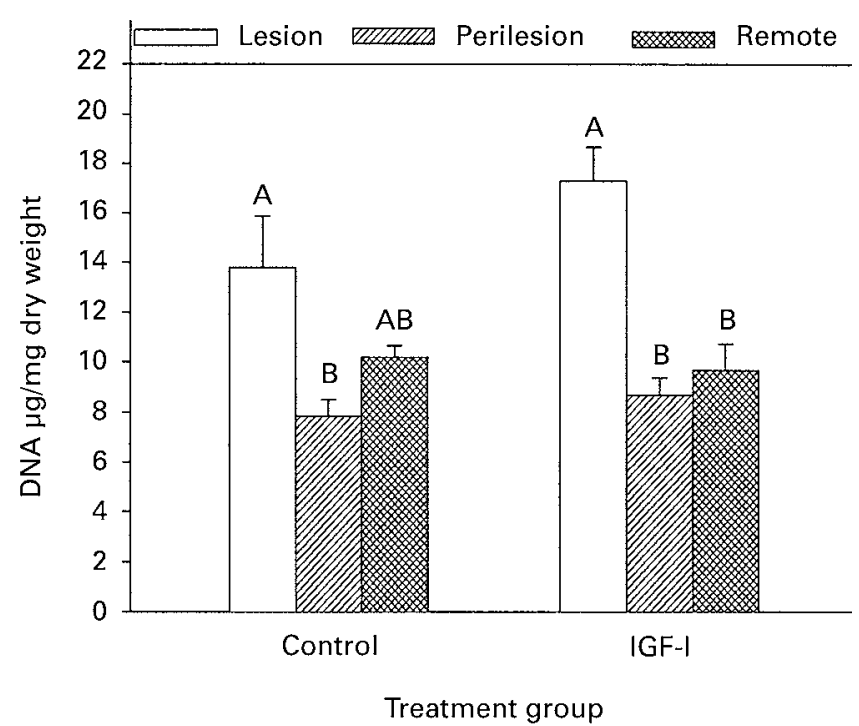

Fig. 6

Mean ( \pm SEM) total DNA content in repair tissue, perilesion $(1 \mathrm{~cm}$ from repair tissue) and remote ( $>2 \mathrm{~cm}$ from repair tissue) cartilage in IGF-Itreated and control joints from eight horses. Tukey's classification letters indicate significant differences between repair tissue, perilesion, and remote cartilage within control or IGF-I-treated groups. There were no significant differences between IGF-I treated and control groups.

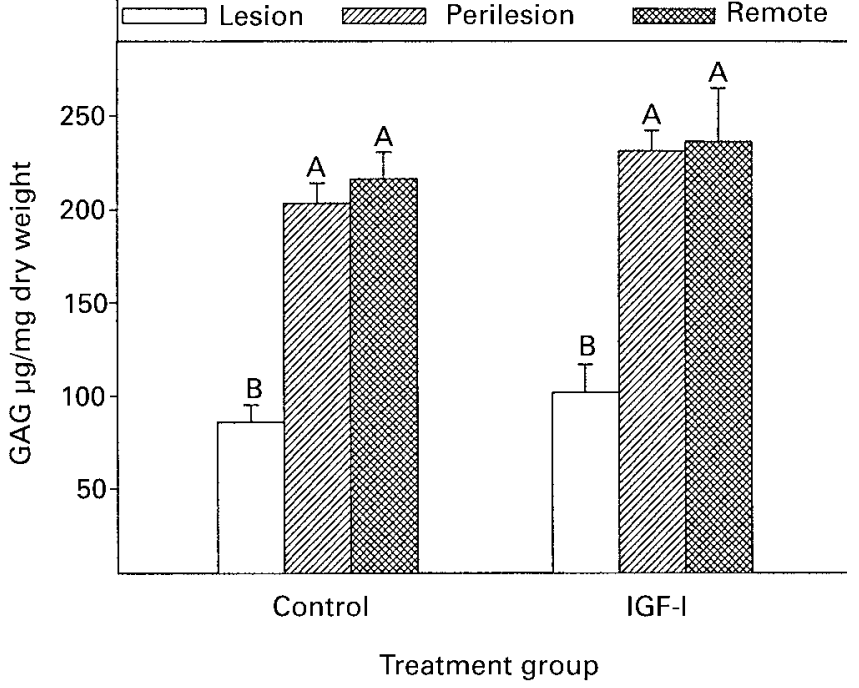

Fig. 7

Mean ( \pm SEM) total glycosaminoglycan (GAG) content in repair tissue, perilesion ( $1 \mathrm{~cm}$ from repair tissue) and remote ( $>2 \mathrm{~cm}$ from repair tissue) cartilage in IGF-I-treated and control joints from eight horses. Tukey's classification letters indicate significant differences between repair tissue, perilesion, and remote cartilage within control or IGF-I-treated groups. There were no significant differences between IGF-I treated and control groups.

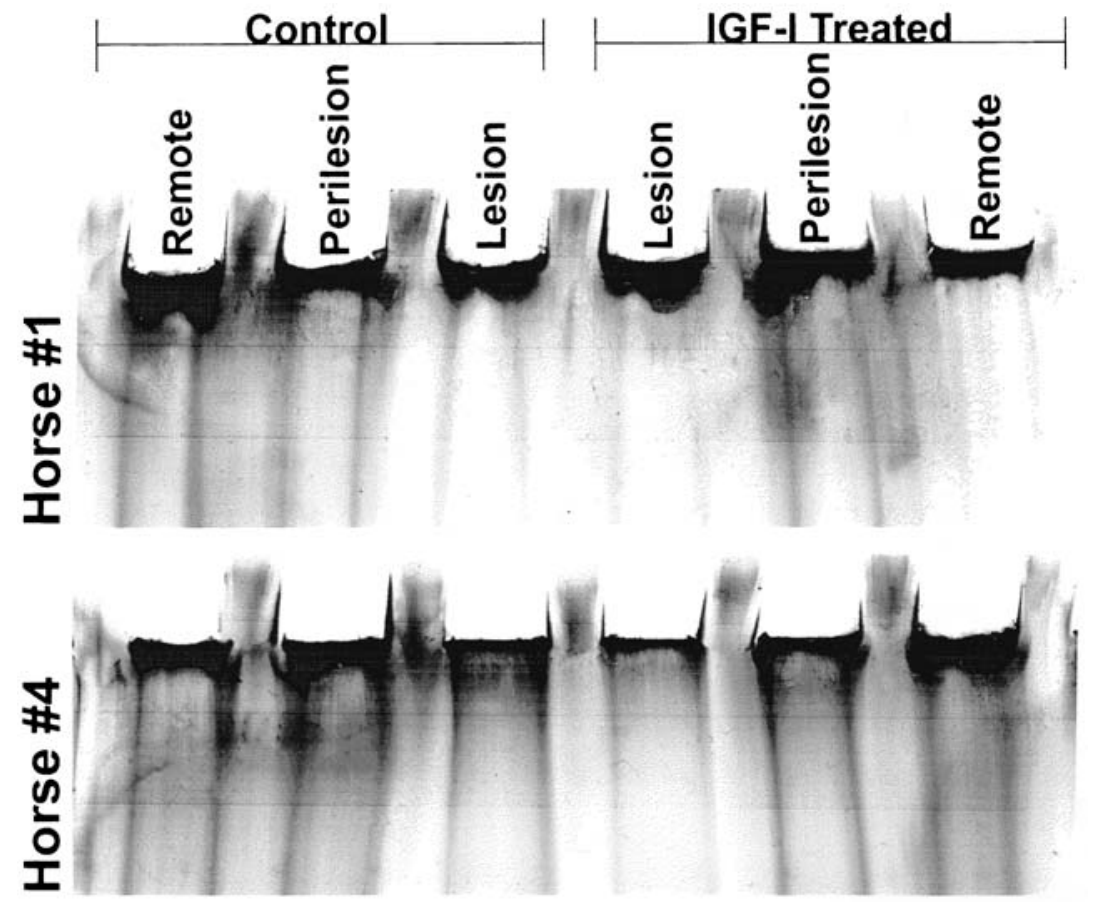

Fig. 8

Toluidine-Blue-stained agarose-acrylamide composite gels following proteoglycan aggregation assay The pattern of aggregation after gel electrophoresis was indistinguishable between proteoglycans extracted from lesion, perilesion and remote cartilage in both the IGF-I-treated and control joints.

histological specimens, with a preponderance of type-II in the IGF-I-treated joints from six of the eight animals. TypeI collagen messenger RNA, however, was also evident in sections from six horses, and type-I collagen was confirmed by immunohistochemistry in seven horses, indicating incomplete chondrogenesis in the repair tissue. In animals in which type-I collagen was detected, the IGF-I-grafted defects contained less type-I message expression and less type-I protein, compared with control grafted defects. In all instances, type-I collagen in situ hybridisation and immunoreaction were less intense than type-II collagen reactions.

Cartilage defects treated with IGF-I were significantly better integrated (gross integration $p=0.030$, histological integration $\mathrm{p}=0.050$ ) with the surrounding cartilage than 
Table IV. The mean ( \pm SEM) total hydroxyproline (pg hydroxyproline/ $\mu \mathrm{g}$ of dry weight) of IGF-I-treated and control-grafted defects derived from HPLC analysis of PITC derivatised, acid-hydrolysed samples from eight horses

\begin{tabular}{lll}
\hline Tissue location & IGF-I-treated & Control \\
\hline Lesion & $594.5 \pm 21.2$ & $560.8 \pm 46.3$ \\
Perilesion & $520.7 \pm 15.4$ & $600.4 \pm 31.1$ \\
Remote & $641.3 \pm 20.1$ & $620.0 \pm 18.9$ \\
\hline
\end{tabular}

Table V. Mean concentration $(\mathrm{ng} / \mathrm{ml} \pm$ SEM) of IGF-I in synovial fluid from IGF-I-treated and control joints from eight horses

\begin{tabular}{lcl}
\hline $\begin{array}{l}\text { Sample time } \\
\text { (days postoperative) }\end{array}$ & IGF-I treated & Control \\
\hline 0 & $56.0 \pm 4.2$ & $72.9 \pm 20.3$ \\
4 & $119.6 \pm 29.2$ & $96.1 \pm 12.6$ \\
7 & $88.2 \pm 8.9$ & $90.5 \pm 12.3$ \\
14 & $87.3 \pm 16.8$ & $72.7 \pm 9.5$ \\
\hline
\end{tabular}

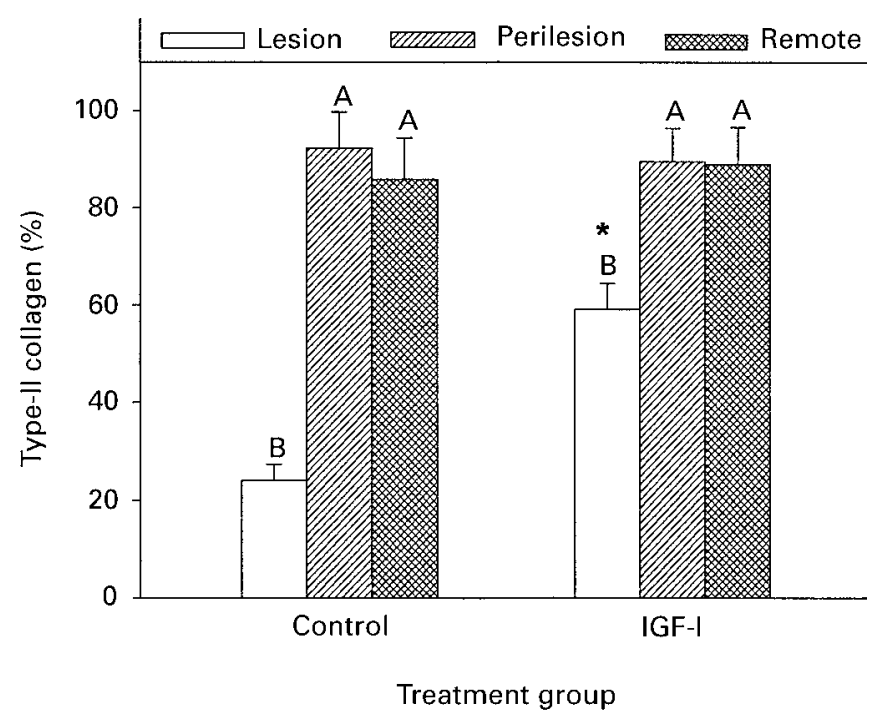

Fig. 9

Mean ( \pm SEM) type-II collagen $(\%)$ in repair tissue of IGF-I-treated and control joints from eight horses. Tukey's classification letters indicate significant differences between repair tissue, perilesion, and remote cartilage within control or IGF-I treated groups. $*$ indicates significant differences in type-II collagen between IGF-I-treated and control sites in repair tissue only. There were no significant differences in type-II collagen in perilesion or remote cartilage between IGF-I-treated and control joints.

in control defects. Improved continuity between repair tissue and host cartilage is important in providing a durable repair, since this interface is typically where defect tissue begins to deteriorate. ${ }^{60,61}$ This is particularly relevant given that these animals were actively exercised for the last six months of the study, and suggests that there is adequate cartilage resilience under normal loads.

The biochemical data did not consistently support gross and histological observations. The percentage of type-II collagen, determined by CNBr-digestion and SDS-PAGE analysis, was significantly increased in IGF-I-treated defects compared with controls, consistent with type-II collagen immunohistochemistry and in situ hybridisation. There were no significant differences, however, in total GAG or DNA between IGF-I-treated and control-grafted defects in this study. The reasons for this discrepancy include localisation of cellular responses to the lower onethird to two-thirds of the repair tissue, which subsequently had a less significant impact when the entire depth of the tissue was considered for biochemical analysis, masking potentially significant differences. Microscopically, the tissue in the upper one-third appears fibrous, but type-I collagen is not being actively transcribed or translated according to our immunohistochemical and in situ hybridisation data. The cells of the upper layers are likely to express a distinct set of molecular markers which we have not investigated. Although the total PG content of repair tissue in both the IGF-I-treated and control grafted defects did not attain that of normal articular cartilage, the PG which was produced was capable of aggregation when examined on agarose-acrylamide composite gel electrophoresis. This suggests the presence of functional aggrecan, which would assist in the restoration of the normal biomechanical function of cartilage because of its impact on the compressive stiffness of articular cartilage. ${ }^{62}$

Intra-articular administration of IGF-I is rarely described. To our knowledge there are only two other reports documenting the use of IGF-I in vivo. ${ }^{15,63}$ In one study, $2 \mu \mathrm{g}$ of IGF-I were injected intra-articularly, three times/ week for three weeks, using a canine model of osteoarthritis with transection of the anterior cruciate ligament. ${ }^{63}$ While the intra-articular administration of $18 \mu \mathrm{g}$ of IGF-I over a three-week period did not aid in the repair of damaged cartilage, no deleterious side-effects were detected histologically or biochemically. The second study assessed histologically the use of IGF-I $(50 \mathrm{ng} / \mathrm{ml}$, total dose not reported) subsequent to the application of chondroitinase $\mathrm{ABC}$ in the repair of partial-thickness cartilage defects. ${ }^{15}$ IGF-I administered topically or in fibrin clots improved the extent of the tissue cover in the cartilage defect, and the IGF-I/fibrin combination improved the cellularity of the repair tissue. In the study reported here, we used a higher concentration and presumably a more sustained exposure to IGF-I by the use of fibrin as a biological polymer from which $25 \mu \mathrm{g}$ of IGF-I could elute. In previous studies in vitro, IGF-I $(25 \mu \mathrm{g})$ incorporated into fibrin discs was found to elute into the culture medium at concentrations greater than $110 \mathrm{ng} / \mathrm{ml}$ for 22 days when chondrocytes were absent, ${ }^{43}$ and at greater than $50 \mathrm{ng} / \mathrm{ml}$ for 14 days when chondrocytes were included in the culture. ${ }^{39}$ In this study, there was no significant elevation in IGF-I in the synovial fluid measured by RIA on postoperative days 4,7 and 14, compared with preoperative values. A strong trend $(p=0.10)$ towards a significant increase in IGF-I was found, however, in the synovial fluid from IGF-I-grafted joints on day 4. These RIA data suggest that most of the initial $25 \mu \mathrm{g}$ of IGF-I was either diluted excessively in the 50 to $100 \mathrm{ml}$ volumes of synovial fluid contained in an 
equine femoropatellar joint, sequestered within the fibrinchondrocyte composite and not available for assay in the synovial fluid, or rapidly eluted and redistributed before postoperative sampling of synovial fluid on day 4. Elution of IGF-I from fibrin-chondrocyte composites in vitro indicates that there is a consistent elution of IGF-I from fibrin over 14 to 21 days. $^{39,43}$ Regardless, as the IGF-I was incorporated into the fibrin, it would have bathed the chondrocytes and bound to available IGF-I receptors. Additionally, IGF-I has autoinductive properties, peaking at 24 hours after exogenous exposure, further extending the IGFI impact on chondrocyte function. ${ }^{64}$ Fibrin polymers containing chondrocytes have previously been used as graft material in an equine model of full-thickness healing of a cartilage defect, with no apparent side-effects such as immunorejection due to transplantation of allogeneic chondrocytes or inflammatory responses resulting from the use of fibrin as a vehicle. ${ }^{44}$ Studies in vitro suggest that IGF-I concentrations in fibrin as low as $50 \mathrm{ng} / \mathrm{ml}$ support the active metabolism of chondrocytes. ${ }^{40}$ In addition, supplementing chondrocyte-fibrin cultures with $25 \mu \mathrm{g}$ of IGF-I stimulated the synthesis of large proteoglycans, DNA, and type-II collagen without inducing signs of IGF-I toxicity, or chondrocyte cloning and dedifferentiation. ${ }^{39}$ The use of fibrin as a biomatrix for chondrocyte transplantation and elution of IGF-I has the added advantage of being arthroscopically applicable, thereby avoiding the morbidity associated with arthrotomy incisions. Fibrin, without added cells, implanted into osteochondral defects in rabbit knees alone or in combination with growth hormone, has not been considered by other investigators to be an acceptable graft material. ${ }^{65}$ The authors concluded that fibrin did not allow cellular penetration and is therefore not suitable as a scaffold for enhanced repair of cartilage. The present study incorporated chondrocytes into the fibrin graft material, and given the relatively sedentary nature of articular chondrocytes, they were not expected to migrate great distances. We have not specifically investigated, however, the mobility of equine chondrocytes in fibrin preparations.

These data suggest that IGF-I-supplemented to chondrocytefibrin articular grafts enhanced the gross appearance of healing cartilage lesions, improved integration with surrounding cartilage, and increased collagen type-II transcription and translation, compared with control grafts in which IGF-I was omitted. While these parameters were improved, type-I collagen was still present, and the total proteoglycan content remained below normal at eight months after operation, indicating incomplete chondrogenesis. The importance of these findings with respect to the functionality and durability of the repair tissue requires further long-term studies with more athletic exercise programmes.

We thank Mr Stephen Bent for his assistance with the RIA analysis. This research was supported by National Institute of Health Individual National Research Service Award AR08360 (LAF) and the Harry M. Zweig Memorial Foundation for Research (AJN, LAF).

No benefits in any form have been received or will be received from a commercial party related directly or indirectly to the subject of this article.

\section{References}

1. Furukawa T, Eyre DR, Koide S, Glimcher MJ. Biochemical studies on repair cartilage resurfacing experimental defects in the rabbit knee. J Bone Joint Surg [Am] 1980;62-A:79-89.

2. Meachim G, Roberts C. Repair of the joint surface from subarticular tissue in the rabbit knee. J Anat 1971;109:317-27.

3. Mankin HJ. The response of articular cartilage to mechanical injury. J Bone Joint Surg [Am] 1982;64-A:460-6.

4. Coletti JM, Akeson WH, Wood SL-Y. A comparison of the physical behavior of normal articular cartilage and the arthroplasty surface. $J$ Bone Joint Surg [Am] 1972;54-A:147-60.

5. Buckwalter JA, Mankin HJ. Articular cartilage repair and transplantation. Arthritis Rheum 1998;41:1331-42.

6. Minas T, Nehrer S. Current concepts in the treatment of articular cartilage defects. Orthopedics 1997;20:525-38.

7. Wirth CJ, Rudert M. Techniques of cartilage growth enhancement: a review of the literature. Arthroscopy 1996;12:300-8.

8. Nixon AJ, Sams AE, Lust G, Grande D, Mohammed HO. Temporal matrix synthesis and histologic features of a chondrocyte-laden porous collagen cartilage analogue. Am J Vet Res 1993;54:349-56.

9. Nehrer S, Breinan HA, Ramappa A, et al. Canine chondrocytes seeded in type I and type II collagen implants investigated in vitro. $J$ Biomed Mater 1997;38:95-104.

10. Aigner J, Bujia J, Hutzler $\mathbf{P}$, Kastenbauer E. Distribution and viability of cultured human chondrocytes in a three-dimensional matrix as assessed by confocal laser scan microscopy in vitro. Cell Dev Biol Anim 1997;33:407-9.

11. Cook JL, Kreeger JM, Payne JT, Tomlinson JL. Three-dimensional culture of canine articular chondrocytes on multiple transplantable substrates. Am J Vet Res 1997;58:419-24.

12. van Susante JL, Buma P, van Osch G, et al. Culture of chondrocytes in alginate and collagen carrier gels. Acta Orthop Scand 1995;66:549-56.

13. Buschmann MD, Gluzband YA, Grodzinsky AJ, Kimura JH, Hunziker EB. Chondrocytes in agarose culture synthesize a mechanically functional extracellular matrix. J Orthop Res 1992;10:745-8.

14. Sams AE, Minor RR, Wootton JA, Mohammed H, Nixon AJ. Local and remote matrix responses to chondrocyte laden collagen scaffold implantation in extensive articular cartilage defects. Osteoarthritis Cartilage 1995;3:61-70.

15. Hunziker EB, Rosenberg LC. Repair of partial-thickness defects in articular cartilage: cell recruitment from the synovium. J Bone Joint Surg [Am] 1996;78-A:721-33.

16. Skantze K, Brinckerhoff C, Collier JP. Use of agarose culture to measure the effect of transforming growth factor $\beta$ and epidermal growth factor on rabbit articular chondrocytes. Cancer Res 1985;45:4416-21.

17. Franchimont P, Bassleer C. Effects of hormones and local growth factors on articular chondrocyte metabolism. J Rheumatol Suppl 1991;27:68-70.

18. Lee DA, Bentley G, Archer CW. The control of cell division in articular chondrocytes. Osteoarthritis Cartilage 1993;1:137-46.

19. Ohya Y, Watanabe K. Control of growth and differentiation of chondrogenic fibroblasts growth factor and transforming growth factor- $\beta$. Zoolog Sci 1994;11:261-7.

20. Tschan T, Bohme K, Conscience-Egli M, et al. Autocrine or paracrine transforming growth factor- $\beta$ modulates the phenotype of chick embryo sternal chondrocytes in serum-free agarose culture. $J$ Biol Chem 1993;268:5156-61.

21. Sellers RS, Peluso D, Morris EA. The effect of recombinant human bone morphogenetic protein-2 (rhBMP-2) on the healing of fullthickness defects of articular cartilage. J Bone Joint Surg [Am] 1997;79-A:1452-63.

22. Flechtenmacher J, Huch K, Thonar EJMA, et al. Recombinant human osteogenic protein 1 is a potent stimulator of the synthesis of cartilage proteoglycans and collagens by human articular chondrocytes. Arthritis Rheum 1996;39:1896-904.

23. Glansbeek HL, van Beuningen HM, Vitters EL, et al. Bone morphogenetic protein 2 stimulates articular cartilage proteoglycan synthesis in vivo but does not counteract interleukin-1 alpha effects on proteoglycan synthesis and content. Arthritis Rheum 1997;40:1020-8 
24. Guerne PA, Blanco F, Kaelin A, Desgeorges A, Lotz M. Growth factor responsiveness of human articular chondrocytes in aging and development. Arthritis Rheum 1995;38:960-8.

25. Malemud CJ. The role of growth factors in cartilage metabolism. Rheum Dis Clin North Am 1993;19:569-80.

26. Morales TI, Hascall VC. Factors involved in the regulation of proteoglycan metabolism in articular cartilage. Arthritis Rheum 1989;32:1197-201.

27. Mankin HJ, Jennings LC, Treadwell BV, Trippel SB. Growth factors and articular cartilage. J Rheumatol 1991;27:66-7.

28. McQuillan DJ, Handley CJ, Campbell MA, et al. Stimulation of proteoglycan biosynthesis by serum and insulin-like growth factor-1 in cultured bovine articular cartilage. Biochem J 1986;240:423-30.

29. Denko CW, Boja B, Moskowitz RW. Growth promoting peptides in osteoarthritis and diffuse idiopathic skeletal hyperostosis: insulin, insulin-like growth factor-I, growth hormone. J Rheumatol 1994;21:1725-30.

30. Wang E, Wang J, Chin E, Zhou J, Bondy CA. Cellular patterns of insulin-like growth factor system gene expression in murine chondrogenesis and osteogenesis. Endocrinology 1995;136:2741-51.

31. Luyten FP, Hascall VC, Nissley SP, Morales TI, Reddi AH. Insulinlike growth factors maintain steady-state metabolism of proteoglycans in bovine articular cartilage explants. Arch Biochem Biophys 1988;267:416-25.

32. Tyler JA. Insulin-like growth factor 1 can decrease degradation and promote synthesis of proteoglycan in cartilage exposed to cytokines. Biochem J 1989;260:543-8.

33. Sah RL, Chen AC, Grodzinsky AJ, Trippel SB. Differential effects of bFGF and IGF-I on matrix metabolism in calf and adult bovine cartilage explants. Arch Biochem Biophys 1994;308:137-47.

34. Sah RL, Trippel SB, Grodzinsky AJ. Differential effects of serum, insulin-like growth factor-I, and fibroblast growth factor-2 on the maintenance of cartilage physical properties during long-term culture. J Orthop Res 1996;14:44-52.

35. Ohlsson C, Nilsson A, Isaksson OG, Lindahl A. Effect of growth hormone and insulin-like growth factor-I on DNA synthesis and matrix production in rat epiphyseal chondrocytes in monolayer culture. J Endocrinol 1992;133:291-300.

36. Osborn KD, Trippel SB, Mankin HJ. Growth factor stimulation of adult articular cartilage. J Orthop Res 1989;7:35-42.

37. Handley CJ, McQuillan DJ, Campbell MA, Bolis S. Steady-state metabolism in cartilage explants. In: Kuettner K, Schleyerbach R, Hascall VC, eds. Articular cartilage biochemistry. New York, Raven Press, 1986:163-79.

38. Franchimont P, Bassleer C, Henrotin Y. Effects of hormones and drugs on cartilage repair. J Rheumatol Suppl 1989;18:5-9.

39. Fortier LA, Nixon AJ, Lust G. Chondrocyte metabolism in threedimensional cultures supplemented with high concentrations of insulin-like growth factor-I. $\mathrm{PhD}$ Thesis, Cornell University, 1998:98-127.

40. Fortier LA, Lust G, Mohammed HO, Nixon AJ. Coordinate upregulation of cartilage matrix synthesis in fibrin cultures supplemented with exogenous insulin-like growth factor-I. $J$ Orthop Res 1999; 17:467-74.

41. Fosang AJ, Tyler JA, Hardingham TE. Effects of interleukin-1 and insulin like growth factor- 1 on the release of proteoglycan components and hyaluronan from pig articular cartilage in explant culture. Matrix 1991;11:17-24.

42. Frisbie DD, Nixon AJ. Insulin-like growth factor 1 and corticosteroid modulation of chondrocyte metabolic and mitogenic activities in interleukin 1-conditioned equine cartilage. Am J Vet Res 1997;58:524-30.

43. Foley RL, Nixon AJ. Insulin-like growth factor-1 peptide elution profiles from fibrin polymers determined by use of high performance liquid chromatography. Am J Vet Res 1997;58:1431-5.

44. Hendrickson DA, Nixon AJ, Grande DA, et al. Chondrocyte-fibrin matrix transplants for resurfacing extensive articular cartilage defects. J Orthop Res 1994;12:485-97.
45. Nixon AJ, Lust G, Vernier-Singer M. Isolation, propagation and cryopreservation of equine articular chondrocytes. Am J Vet Res 1992;53:2364-70.

46. Cohn EJ, Strong LE, Hughes WL, et al. Preparation and properties of serum and plasma proteins: IV: a system for the preparation into fractions of the protein and lipoprotein components of biological tissues and fluids. J Amer Chem Soc 1946;68:459-75.

47. Sandell LJ. In situ expression of collagen and proteoglycan genes in notochord and during skeletal development and growth. Microsc Res Tech 1994;28:470-82.

48. Kim Y-J, Sah RL, Doong J-Y, Grodzinsky AJ. Fluorometric assay of DNA in cartilage explants using Hoechst 33258. Anal Biochem 1988; $174: 168-76$.

49. Farndale RW, Buttle DJ, Barrett AJ. Improved quantitation and discrimination of sulphated glycosaminoglycans by use of dimethylmethylene blue. Biochem Biophys Acta 1986;883:173-7.

50. McDevitt CA, Muir H. Gel electrophoresis of proteoglycans and glycosaminglycans on large-pore composite polyacrylamide-agarose gels. Anal Biochem 1971;44:612-22.

51. Carney SL, Bayliss MT, Collier JM, Muir H. Electrophoresis of 35 S-labelled proteoglycans on polyacrylamide-agarose composite gels and their visualisation by fluorography. Anal Biochem 1986;156:38-44.

52. Green GD, Reagan K. Determination of hydroxyproline by high pressure liquid chromatography. Anal Biochem 1992;201:265-9.

53. Bradford MM. A rapid and sensitive method for the quantitation of microgram quantities of protein utilizing the principle of protein-dye binding. Anal Biochem 1976;72:248-54.

54. Little CB, Hilbert BJ, Wickstrom S, Hedlund BE. Quantitative microanalysis of equine synovial fluid glycosaminoglycan concentration. Am J Vet Res 1990;51:1534-9.

55. Schalkwijk J, Joosten LA, van den Berg WB, van de Putte LB. Chondrocyte nonresponsiveness to insulin-like growth factor 1 in experimental arthritis. Arthritis Rheum 1989;32:894-900.

56. Curtis AJ, Ng CK, Handley CJ, Robinson HC. Effect of insulin-like growth factor-I on the synthesis and distribution of link protein and hyaluronan in explant cultures of articular cartilage. Biochem Biophys Acta 1992;1135:309-17.

57. Tesch GH, Handley CJ, Cornell HJ, Herington AC. Effects of free and bound insulin-like growth factors on proteoglycan metabolism in articular cartilage explants. $J$ Orthop Res 1992;10:14-22.

58. Nixon AJ, Fortier LA, Williams J, Mohammed H. Enhanced repair of extensive articular defects by insulin-like growth factor-I-laden fibrin composites. J Orthop Res 1999;17:475-87.

59. Fortier LA, Balkman CE, Sandell LJ, Ratcliffe A, Nixon AJ. Insulin-like growth factor-1 gene expression patterns during repair of acute articular cartilage injury. J Orthop Res 2001;19:720-8.

60. Buckwalter J, Rosenberg L, Coutts R, et al. Articular cartilage: injury and repair. In: Woo SL-Y, Buckwalter JA, eds. Injury and repair of the musculoskeletal soft tissues. Park Ridge, Illinois: AAOS, 1988:465-82.

61. Mankin HJ. The reaction of articular cartilage to injury and osteoarthritis. N Engl J Med 1974;291:1285-92.

62. Hascall VC, Kimura JH. Proteoglycans: isolation and characterization. In: Cunningham LW, Frederikson DW, eds. Methods in enzymology: structural and contractile proteins. New York, Academic Press, 1982:769-800.

63. Rogachefsky RA, Dean DD, Howell DS, Altman RD. Treatment of canine osteoarthritis with insulin-like growth factor-1 (IGF-1) and sodium pentosan polysulfate. Osteoarthritis Cartilage 1993;1:105-14.

64. Nixon AJ, Saxer RA, Brower-Toland BD. Exogenous IGF-I stimulates an autoinductive response in chondrocytes. J Orthop Res 2000; in review:597.

65. Brittberg M, Sjogren-Jansson E, Lindahl A, Peterson L. Influence of fibrin sealant (Tisseel) on osteochondral defect repair in the rabbit knee. Biomaterials 1997;18:235-42. 